\title{
THE IMPACT OF MOTIVATIONAL INCENTIVES ON EMPLOYEE PERFORMANCE
}

\author{
Dr. C K GOMATHY, Mr. PUSULURI SAI VENKATA AKSHAY, Mr. KALYAN TANTRAVAHI,
} Mr. TEKUMALLA HARSHAVARDHAN VARMA.

Sri Chandrasekharendra Saraswathi Viswa Mahavidyalaya, Kanchipuram

\begin{abstract}
Over the long haul, there has been a consistent expansion in most Indian enterprises, the emergency is a consequence of helpless working conditions, rigid principles, poor and deferred instalment of laborers' wages and compensations. Again, the emergencies likewise result from the disappointment of the top administration to appreciate to the human component as the most pivotal element and the determinant of accomplishment of objectives and destinations this outcome into dissatisfaction which shows itself distinctively by individual or laborers. It is a perspective on this that this exploration expects to check out the impact of inspiration on worker execution in an association taking India packaging organization plc as a contextual investigation.
\end{abstract}

Keywords: Employee's motivation, Compensation, Contextual analysis, Employee performance, incentives.

\section{INTRODUCTION}

Since the beginning of the time, pioneers have ascended to assume responsibility for social orders and decide. These choices regularly implied the contrast between being effective and being a disappointment, having cover or being destitute, and here and there the distinction among life and passing. As society advanced, there have been extraordinary innovative advances that have carried a significant degree of accommodation to our lives.
Regardless of having progressions, the essential requirements for people continue as before. An inquiry regularly posed by business chiefs is, "How would we persuade our representatives to guarantee ideal execution?" Adequately rousing workers to accomplish the ideal result is one of the main elements of a business director. There are pointers to show that business associations are confronting moves holding workers because of restricted open doors for headway and the current serious work market in India. It doesn't seem things will improve later on. The deficiency of representatives implies loss of abilities, information, and encounters and can make a huge financial effect and cost to companies just as affecting the requirements of clients/customers. Business chiefs who can propel representatives to help the association by further developing worker maintenance and supporting positive practices and thus, their suffering capacity to successfully rouse laborers to accomplish the most elevated outcome decides the degree of achievement of a business. Inspiration is the expectation of accomplishing a target or point, a capacity to change conduct, that inward coordinating drive, prompting objective coordinated conduct towards the achieving objective. Inspirational prizes/motivations can be either nonfinancial or money related. For inspiration to be available, the chief must both worth advancement and see the connection between his endeavors and advancement. In this way, for a singular award or result, the contention is that a blend of its worth and 


\section{International Journal of Scientific Research in Engineering and Management (IJSREM)}

the proper exertion reward likelihood is fundamental. Nonetheless, a singular's inspiration is impacted by more than one result. Subsequently, to decide a singular's inspiration, it is important to consolidate information worried about a few unique results. One of the serious issues defying the board today is that of propelling to perform appointed undertaking to meet or outperforms the foreordained norm. Inspiration is that invigorating power that actuates or urges and keeps up with conduct. It isn't not difficult to inspire a person, for the achievement of any persuasive exertion relies upon the degree to which the inspiration addresses the issues of the singular representatives for whom it is planned. Inspiration is an inside mental interaction whose presence or nonappearance is expected from noticed execution.

In India today, absence of appropriate administrative information, financial downturn and high pace of joblessness have made most specialists oppressed, to unfortunate working conditions, which obviously are the impetus of low execution. The administration of most associations will in general accept that specialists are happy with their work yet they are not, tragically. Work fulfilment surmises going to work and finishing accepted of work. In India, more often than not, the compensation given to a specialist isn't commensurable to the sort of work done. This is the justification for why some of the time proficient and experience specialist leaves an association for one more association that pay more or remain in the association and perform underneath assumption. Work disappointment is very pervasive in many associations. The low presentation which comes because of occupation disappointment is generally the reason for struggle among associations and laborers. Chiefs generally fault the laborers for not placing in their best, and on side of the specialists, they fault the board for not giving or establishing an empowering climate as in inspiration. Whoever might be blameworthy, the main concern is fulfilling the target of the association, which obviously is to create sufficient gain to keep the association moving. To meet the above object there need for both the administration and representative to arrive at an agreement, the administration meeting the cravings of the laborers and thusly the workers put in their best as far as execution. The specialists need the security, everything being equal; physical, mental and financial are significant for compelling and effective execution.

\section{SIGNIFICANCE OF THE STUDY}

The review could be helpful to Indian packaging organizations and for sure different associations in India and past in further developing their level of usefulness and worker's presentation in future. It will likewise help the board in settling on choices on how representatives could be inspired, with cash as well as different impetuses. The review would likewise help understudies, analysts and researchers who are keen on growing further examinations on the topic.

\section{III.PROBLEM STATEMENT}

Over the long haul, there has been a consistent expansion in most Indian ventures, the emergency is a consequence of helpless working conditions, rigid standards, poor and deferred installment of laborers' wages and pay rates.

Again, the emergencies additionally result from the disappointment of the top administration to appreciate to the human component as the most essential element and the determinant of accomplishment of objectives and goals this outcome into dissatisfaction which shows itself diversely by individual or laborers. It is a perspective on this that this exploration plans to check out the impact of inspiration on representative 


\section{International Journal of Scientific Research in Engineering and Management (IJSREM)}

execution in an association taking India packaging organization plc as a contextual analysis.

\section{AIMS AND OBJECTIVES OF THE STUDY}

The significant point of the review is to look at the effect of persuasive motivations on worker execution. Other explicit targets of the review incorporate;

1. To look at the significance of worker execution to hierarchical execution.

2. To evaluate the current degree of persuasive motivating forces at the Indian packaging organization.

3. To inspect the connection between persuasive motivating forces and worker execution.

4. To analyze the effect of persuasive impetuses on hierarchical execution.

5. To look at the connection between representative execution and authoritative execution.

6. To suggest alternate approaches to improving representative execution.

\section{INCENTIVES IN THE WORKPLACE}

An incentive is any significant or wanted thing, item, activity, or occasion that urges a representative to perform a greater amount of the great work that the prize acknowledgment recognizes. Inside a workplace, incentive can go from a monetary motivating force to nonmonetary acknowledgment.

Bosses consistently utilize a motivation framework to build worker commitment and representative execution levels. Compensating representative execution and perceiving great work can uphold long haul upgrades to business main concern productivity.
An incentive program will increase a company's overall profits by $\$ 104,000$ a week on average and will additionally increase employee motivation by $85 \%$.

An incentive system is one of several long-term employee engagement and employee performance strategies that business professionals should consider in order to optimize their work environment and bottom line.

\section{VI.RESULTS}

The research leads to the improvement of the level of productivity of organizations and employee's performance. It also benefits students, researchers and scholars who are interested in developing further studies on the subject matter.

\section{CONCLUSION}

The above outcomes show that representatives are more equipped to have an extremely useful demeanor when their work is been compensated. As a rule, they wish to get compensated monetarily more than getting leave or having persuasive discussions. Some need to get elevated to higher administration positions. For them that is an extraordinary arrangement of acknowledgment for nicely done and furthermore a decent inspiration. It is subsequently of principal significance that organizations ought to have generally excellent persuasive systems set up to get their representatives at most extreme efficiency. They will generally esteem their compensation bundles more than the relationship they have with different specialists at the organization as a significant inspiration for hands on execution.

\section{VIII.REFERENCES}

- Mak L, Sockel H (2001) A confirmatory factor analysis of IS employee motivation 


\section{International Journal of Scientific Research in Engineering and Management (IJSREM)}

and retention, Information and Management, 38: $265-276$

- Brenda L. Mak.

- Ali, A. Abrar, M. \& Haider J. (2012). Impact of Motivation on the working performance of employees- A case study of Pakistan: Global Advanced Research Journal of Management and Business Studies Vol.1(4), pp. 126-133.

- Leete L (2000), Wage equity and employee motivation in nonprofit and for-profit organizations, Journal of Ecnomics Behavior \& Organization. 43: 423-446.

- Ahmad, M. Wasay, E. \& Malik, S. (2012). Impact of Employee Motivation on Customer Satisfaction:

- Study of Airline Industry in Pakistan: Interdisciplinary Journal of Contemporary Research in Business, Institute of Interdisciplinary Business Research, Vol. 4, No. 6.

- Anyim, C. Chidi, O. \& Badejo, A. (2012). Motivation and Employees' Performance in the Public and Private Sectors in Nigeria: International Journal of Business Administration Vol. 3, No. 1.

- Agwu, M. (2012). Impact of Employees Safety Culture on Organisational Performance in Shell Bonny Terminal Integrated Project (BTIP): European Journal of Business and Social Sciences, Vol. 1, No. 5, pp 70-82.

- Glen K (2006). Key skills retention and motivation: the war for talent still rages and retention is the high ground, 3(1): 37-45.

\section{AUTHOR'S PROFILE: -}

1)

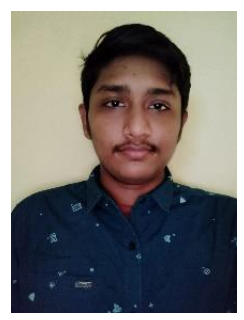

Mr. Pusuluri Sai Venkata Akshay, Student, B.E Computer Science and Engineering, Sri Chandrasekharendra Saraswathi Viswa Mahavidyalaya, Enathur, Kanchipuram, India. His area of interest is in Software Development and Human Resources Development.

2)

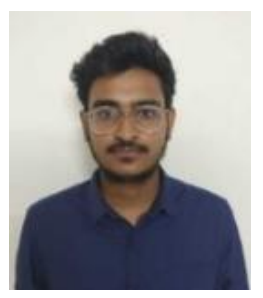

Mr. Kalyan Tantravahi, Student, B.E. Computer Science and Engineering, Sri Chandrasekharendra Saraswathi Viswa Mahavidyalaya, Enathur, Kanchipuram, India. His area of interest is in in Software Development and Human Resources Development.

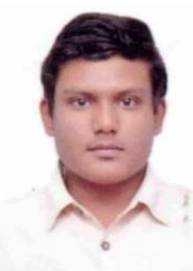

Mr. Tekumalla Harshavardhan Varma, Student, B.E Computer Science and Engineering, Sri Chandrasekharendra Saraswathi Viswa Mahavidyalaya, Enathur, Kanchipuram, India. His area of interest is in in Software Development and Human Resources Development. 
4)

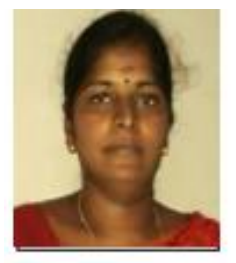

Dr. C.K. Gomathy is Assistant Professor in Computer Science and Engineering at Sri Chandrasekharendra Saraswathi Viswa Mahavidyalaya, Enathur, Kanchipuram, India. Her area of interest is in Software Engineering, Web Services, Knowledge Management and IOT. 